\title{
Studi Peningkatan Output Modul Surya dengan menggunakan Reflektor
}

\author{
Anita Eka Febtiwiyanti* dan Satwiko Sidopekso \\ Jurusan Fisika, Fakultas Matematika dan Ilmu Pengetahuan Alam, \\ Universitas Negeri Jakarta (UNJ) \\ Jl. Pemuda No. 10, Rawamangun, Jakarta 13220
}

\begin{abstract}
Intisari
Upaya mengoptimalkan output daya modul surya dengan menggunakan cermin. Pada penelitian ini digunakan 2 buah cermin datar sebagai solar reflektor dipasang disisi kanan dan kiri dari modul surya. Pengukuran dilakukan dengan mengarahkan posisi modul surya guna mendapatkan hasil yang optimum dengan sudut reflector $50^{\circ}, 60^{\circ}, 70^{\circ}$. Berdasarkan hasil pengukuran didapatkan perolehan daya maksimal pada modul surya menggunakan sudut reflektor $60^{\circ}$, kenaikan daya keluaran $92,7 \%$ dibandingkan tanpa menggunakan reflektor.
\end{abstract}

KATA KUNCI: reflektor, modul surya, daya keluaran

\section{PENDAHULUAN}

Energi merupakan salah satu kebutuhan utama dalam kehidupan manusia. Peningkatan kabutuhan energi dapat merupakan indikator peningkatan kemakmuran, namun bersamaan dengan itu juga menimbulkan masalah dalam usaha penyediaannya, karena manusia hanya mengandalkan energi fosil yang tentunya persediannya masih sangat terbatas dan semakin menipis. Karena tergolong unrenewable, maka akibat dikuras terus-menerus, persediaan energi tersebut semakin berkurang dan tidak bisa diupayakan kembali keberadaanya. Sehingga bukan suatu hal yang mustahil jika dimasa-masa yang akan datang akan timbul masalah-masalah yang berkaitan dengan krisis energi. Untuk mengantisipasi persedian energi di masa yang akan datang, sejak dua dekade terakhir sejumlah pakar energi dari berbagai negara saling berlomba untuk mengupayakan penemuan-penemuan baru tentang sumber energi alternatif yang tidak saja efisien tetapi juga bernuansa ramah lingkungan. Salah satu pilihannya adalah sel surya, walaupun efisiensinya masih perlu pertimbangan lebih jauh.

Dampak dari efisiensi sel surya yang rendah ini, berpengaruh pada hasil output daya listrik pada panel surya. Perlu upaya untuk mengoptimalkan output daya listrik modul surya agar efisiensinya meningkat. Salah satu solusi yang memungkinkan yaitu dengan menambah jumlah cahaya yang mengenai permukaan modul surya dengan bantuan solar reflector. Penggunakan solar reflector, memungkinkan jumlah sinar matahari yang jatuh pada area permukaan modul surya akan lebih banyak, dan hal ini menyebabkan output daya listrik yang dihasilkan akan lebih besar. Jadi dengan adanya peningkatan output daya listrik yang dihasilkan, maka nilai efisiensinya juga akan meningkat.

\footnotetext{
*E-MAIL: sidopekso61@yahoo.com.au
}

\section{LANDASAN TEORI}

Sel surya sebenarnya adalah sebuah sel fotovoltaik yang berfungsi sebagai pengkonversi energi cahaya matahari menjadi energi listrik dalam bentuk arus searah secara langsung. Pada saat sel surya terkena cahaya yang mempunyai $\mathrm{E}_{g}>1$ $\mathrm{eV}$, maka terjadilah hubungan elektron dan hole melalui bahan semikonduktor ini. Maka timbullah aliran elektron pada satu arah dan juga timbul aliran hole pada satu arah yang berlawanan dan timbul aliran arus yang bila dihubungkan pada suatu beban akan menimbulkan tenaga listrik. Pada saat sumber cahaya tiba-tiba dimatikan, maka konsentrasi masingmasing elektron dan hole akan kembali seperti saat awal dimana belum diberi cahaya. Proses kembalinya konsentrasi elektron dan hole pada keadaan semula ini dikenal sebagai proses rekombinasi. Jadi pada sel surya tidak akan ada penyimpanan energi, energi akan hilang begitu terjadi proses rekombinasi. Elektron dan hole bebas diusahakan keluar melewati suatu beban luar dan memberikan energi kepada beban tersebut, hal ini jelas membutuhkan life time yang tinggi atau recombination rate yang rendah. Pemisahan elektron dan hole bebas pada photovoltaic cell dilakukan internal field atau yang disebut $\mathrm{p}-\mathrm{n}$ junction yang terbentuk pada perbatasan bahan semikonduktor tipe $\mathrm{p}$ dan tipe $\mathrm{n}$.

Pada saat sel surya terkena cahaya, maka sel surya akan menerima energi dari foton ke electron yang bergerak bebas pada lapisan tipe-n, sehingga dengan adanya pemberian energi dari foton tersebut, maka electron bebas pada lapisan tipe-n memiliki energi tambahan untuk pindah ke lapisan tipe-p. sehingga pada lapisan tipe-n bersifat lebih positif dari lapisan tipe-p, karena ada beberapa jumlah proton yang lebih besar dari pada jumlah electron. Lalu electron bebas tersebut masuk ke dalam lapisan tipe-p, electron akan memasuki hole yang ada pada lapisan tipe-p. sehingga lapisan tipe-p ini akan bersifat lebih negative, karena ada beberapa atom yang memiliki jumlah proton lebih sedikit dari jumlah elektronnya. Jika lapisan tipe-p dan tipe-n dihubungkan dengan beban, maka akan mengalir arus dari lapisan tipe-n menuju tipe-p. 
Besarnya energi cahaya yang dapat diserap oleh sel surya adalah bergantung terhadap besarnya energi foton dari sumber cahaya. Besar energi cahaya yang mungkin dapat diserap oleh sel surya

$$
E=h f
$$

Intensitas energi suatu sumber cahaya terhadap sel surya

$$
J \approx \frac{1}{R^{2}}
$$

Jika luas permukaan sel surya (A) dengan intensitas tertentu, maka daya input sel surya adalah :

$$
P_{i n}=J A
$$

Semakin besar daya input yang diberikan, maka daya listrik yang dapat dihasilkan oleh sel surya semakin besar. Daya listrik adalah besaran yang diturunkan dari nilai tegangan dan arus sehingga sehingga nilai tegangan dan arus yang dihasilkan merupakan bagian dari kelistrikan yang dimiliki oleh sel surya. Daya listrik yang diberikan oleh sel surya adalah :

$$
P_{\text {sel }}=V_{\text {sel }} I_{\text {sel }}
$$

Efisiensi keluaran maksimum $(\eta)$ didefinisikan sebagai prosentase daya keluaran optimum terhadap energi cahaya yang digunakan, yang dituliskan sebagai :

$$
\eta=\frac{P_{\text {out }}}{P_{\text {in }}} \times 100
$$

Selain efisiensi, karakteristik yang lainnya adalah faktor pengisi (fill factor, FF). Fill factor (FF) merupakan nilai rasio tegangan dan arus pada keadaan daya maksimum dan tegangan open circuit $\left(\mathrm{V}_{o c}\right)$ dan arus short circuit $\left(\mathrm{I}_{s c}\right)$. Hal ini berarti bahwa daya yang dimiliki oleh sel surya belum tentu dapat diberikan kepada beban sepenuhnya. Harga fill factor yang ideal 0,7 sampai 0,85 .

$$
\begin{gathered}
F F=\frac{V_{M P P} \times I_{M P P}}{V_{o c} \times I_{S C}} \\
P_{\text {out }}=V_{o c} \times I_{S C} \times F F
\end{gathered}
$$

\section{A. Efek Perubahan Intensitas Cahaya dan Temperatur Pada Sel Surya}

Apabila energi cahaya yang diterima sel surya berkurang atau intensitasnya melemah, maka besar tegangan dan arus listrik yang dihasilkan juga akan menurun (Gambar 1.a). Sel surya akan beroperasi secara maksimum jika temperatur sel tetap normal (pada $250{ }^{\circ} \mathrm{C}$ ), kenaikan temperatur lebih tinggi dari temperature normal pada sel surya akan melemahkan tegangan $\left(\mathrm{V}_{o c}\right)$ (Gambar 1.b).

Pengoperasian sel surya agar didapatkan nilai yang maksimum juga tergantung pada faktor-faktor antara lain

1. Orientasi dari rangkaian modul surya ke arah matahari secara optimum adalah penting agar panel dapat menghasilkan energi maximum. Sebagai guidline: untuk lokasi yang terletak di belahan Utara latitude, maka panel sebaiknya diorientasikan ke Selatan.

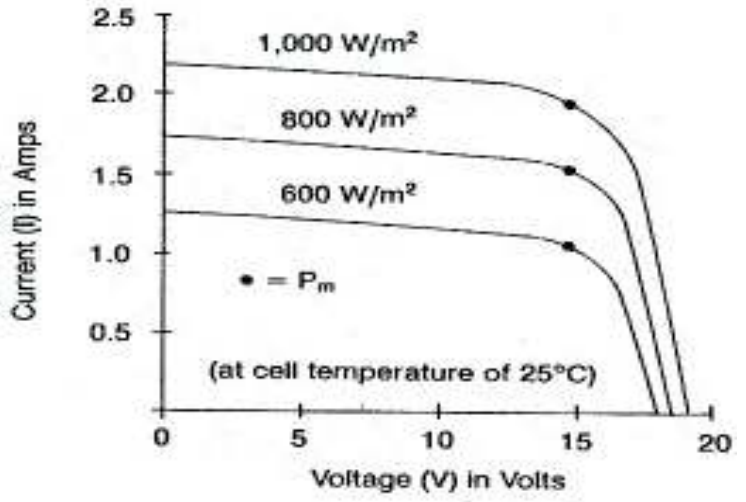

(a)Intensitas

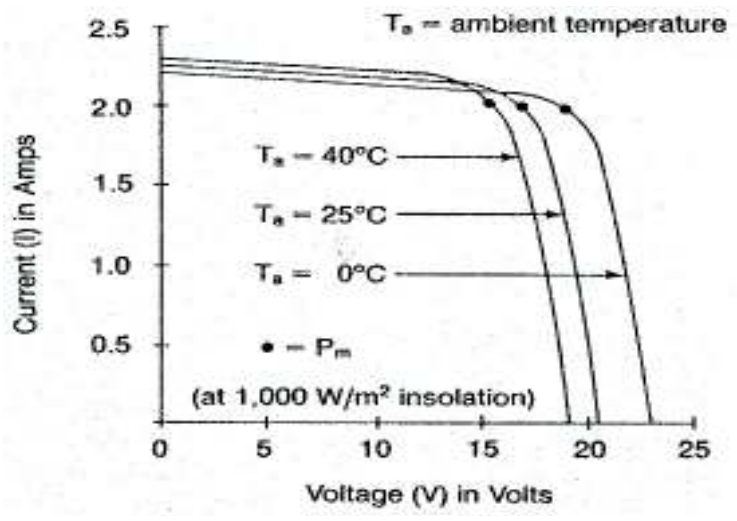

(b)Temperatur

Gambar 1: Kurva efek perubahan intensitas dan temperatur

2. Tilt Angle (sudut orientasi Matahari) Mempertahankan sinar matahari jatuh ke sebuah permukaan modul surya secara tegak lurus akan mendapatkan energi maximum $\mp 1000 \mathrm{~W} / \mathrm{m}^{2}$.

\section{B. Upaya Untuk Mendapatkan Radiasi yang Lebih Banyak}

Ada beberapa cara yang dapat dilakukan dalam upaya mendapatkan radiasi matahari diantaranya:

1. Menggunakan alat yang dapat mengikuti pergerakan matahari

2. Menambah luasan bidang permukaan panel surya

3. Memiringkan kedudukan panel ke suatu arah dengan sudut kemiringan sebesar lintang lokasi daerah itu berada

4. Menggunakan solar reflektor 


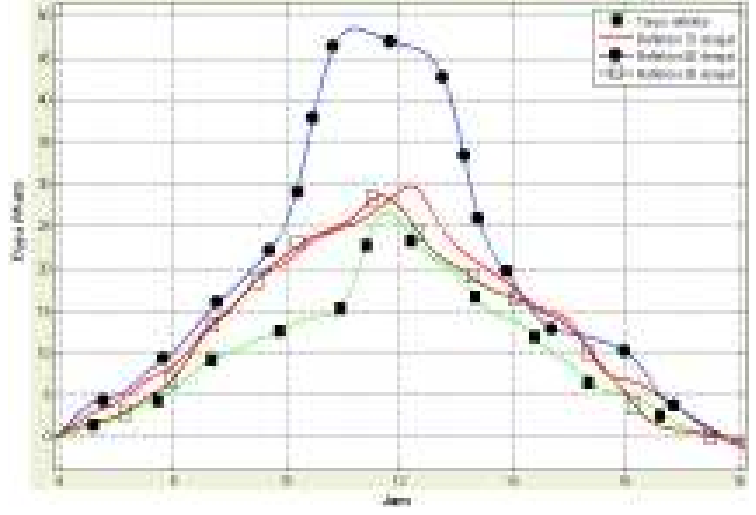

Gambar 2: Perolehan Daya (Reflector 700, 600, 500 dan Tanpa Reflektor)

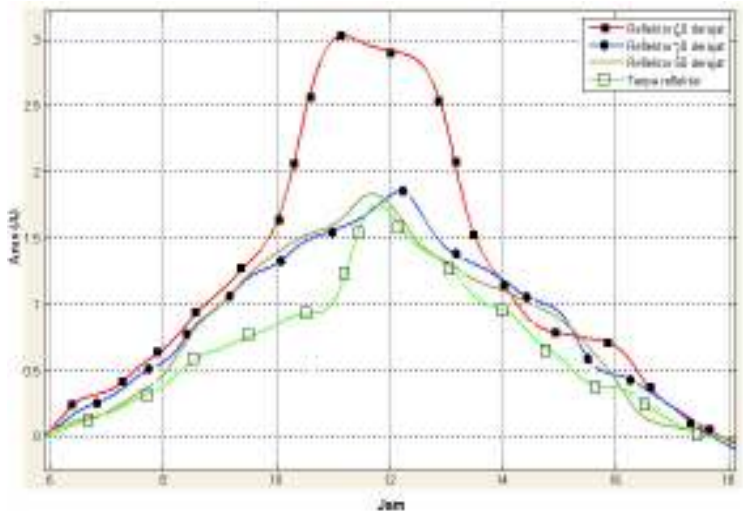

(a)Intensitas

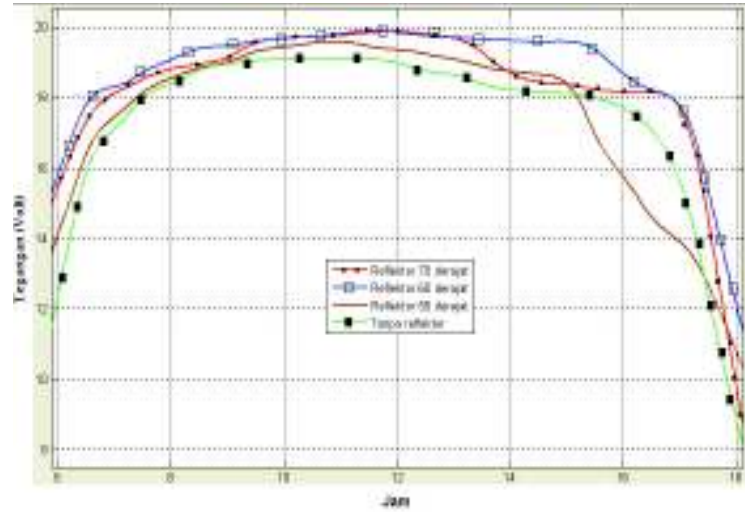

(b)Temperatur

Gambar 3: Perbandingan $\mathrm{I}_{s c}$ dan $\mathrm{V}_{o c}$ menggunakan Reflector 700, 600, 500 dan Tanpa Reflektor

\section{HASIL}

Hasil karakterisasi ditunjukkan Gambar 3 - 5. Berdasarkan grafik pada Gambar menunjukan bahwa peningkatan daya paling besar terjadi pada penggunaan reflektor dengan besar

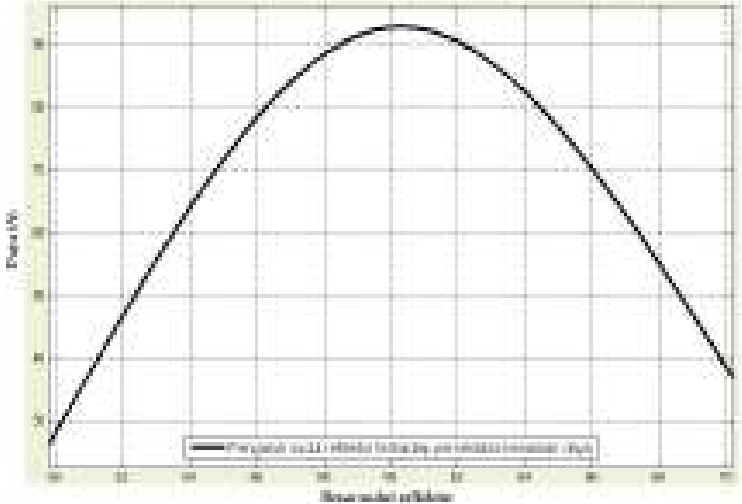

Gambar 4: Pengaruh Sudut Reflektor Terhadap Prosentase Perolehan Daya

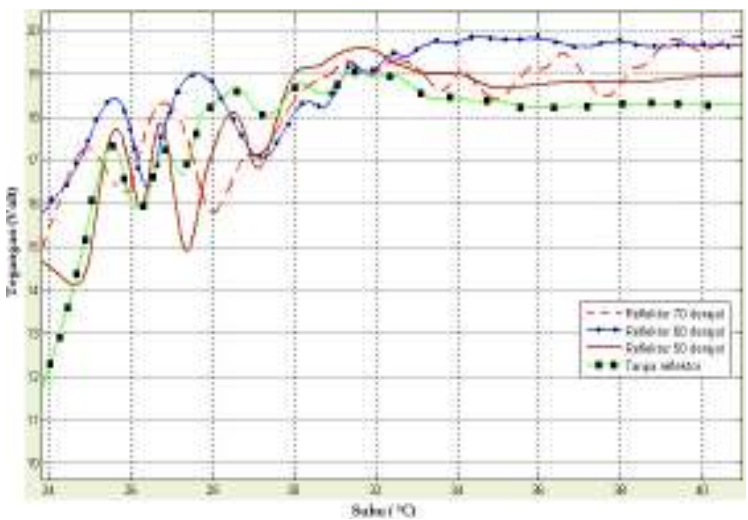

Gambar 5: Perubahan Temperature

sudut $60^{\circ}$ yaitu sebesar $92,76 \%$, sedangkan tingkat kenaikan terkecil terjadi pada penggunaan reflektor dengan sudut $50^{\circ}$ yaitu sebesar $27,96 \%$.

\section{SIMPULAN}

1. Untuk mendapatkan perolehan output daya yang maksimal pada modul surya, maka posisi modul surya diarahkan ke utara.

2. Sudut kemiringan kedudukan modul surya sangat mempengaruhi perolehan output daya pada modul surya

3. Sudut dari reflector diatur lebih besar dari 45 derajat agar reflector dapat bekerja secara optimal dalam menambah jumlah radiasi matahari yang jatuh pada modul surya

4. Kenaikan daya terbesar pada penggunaan reflector dengan kemiringan 60 derajat. 
[1] Free Burma Rangers, Solar Electric Sistem Manual For Free burma Rangers Training Center, 2008.

[2] http://energisurya.files.wordpress.com/2007/11/solar-celldescription.jpg., 24 Januari 2010, pkl 15.14 WIB

[3] Jaka, Elang, Pengaruh Daya RF Terhadap Sifat Listrik Lapisan Tipis a-Si:H yang di Tumbuhkan Dengan Metode HWC-VHFPECVD, Skripsi Jurusan Fisika UNJ, 2009.

[4] R. McConnell,Concentrator Photovoltaic Qualification Stan- dars for System Using Refractive and Reflektive Optics (Paris, France, 2004)

[5] Santoso, Danny, Stategi Aplikasi Sel Surya (Photovoltaic cells) pada Perumahan dan Bangunan Komersil, Surabaya, 2000.

[6] Tim Fotovoltaik UPT LSDE, BPP Teknologi, Pembangkit Listrik Tenaga Surya Penerangan Rumah (SHS), Jurnal BPP Teknologi (1995). 